\section{SOI: $1.1 /$ TAS DOI: $10.15863 /$ TAS International Scientific Journal Theoretical \& Applied Science}

p-ISSN: 2308-4944 (print) ｅ-ISSN: 2409-0085 (online)

Year: $2016 \quad$ Issue: $5 \quad$ Volume: 37

Published: $30.05 .2016 \quad$ http://T-Science.org
Gary B. Lapiz

B.P.A., M.P.A., D.P.A.

Resident Faculty, Department of Public Governance

College of Arts and Sciences

Cebu Normal University, Cebu City, Philippines instructor_lapiz@yahoo.com.ph

SECTION 19. Management. Marketing. Public Administration.

\title{
JUSTICE IN A DEMOCRACY: A SIMPLIFICATION
}

Abstract: Philippines, a democratic and a republican state, espouses on the basics of justice as per specified under the 1987 Constitution. In relation to the aforementioned statement, this expository paper revisits justice in light of the basics of the Bill of Rights (1987 Philippine Constitution: Article III). This framework serves as a guide for all citizens alike and for those who are in governance to observe the merits of law and its principles towards the achievement of justice that even if it could not be perfected in its reality, however, its approximation is near to the projected target of good governance, the aim of all states and entities in the world. This paper should not be construed to be perfect in nature, such that, any kind of suggestions will be helpful towards subsequent editions.

Key words: Philippines, Justice, Bill of Rights, Democracy, Constitution.

Language: English

Citation: Lapiz GB (2016) JUSTICE IN A DEMOCRACY: A SIMPLIFICATION. ISJ Theoretical \& Applied Science, 05 (37): 12-15.

Soi: http://s-o-i.org/1.1/TAS-05-37-2 Doi: crossef http://dx.doi.org/10.15863/TAS.2016.05.37.2

\section{INTRODUCTION}

Justice is the concept of moral rightness in action or attitude; it is closely linked to fairness. A conception of justice is one of the key features of society (Wikipedia) that is notable in any political entity.

Meriam-Webster's Pocket Dictionary (1995) defines justice as:

"jus.tice \'jəstəs $\backslash n$ 1: administration of what is just 2: judge 3: administration of law 4: fairness."

Justice is fairness. It means that a person is considered just when he is fair and fair when he is just. Such notion is very ideal that is difficult in practice. However, justice can be achieved (injustice minimized) if one knows his rights and use it for the purpose of oneself for others and the benefit of the least advantaged in the society.

In 1971, Rawls published his magnum opus entitled, A Theory of Justice and his Justice as Fairness: A Restatement in 2001 respectively. Wenar (2008) states that Rawls constructs justice as fairness around specific interpretations of the defining liberal ideas that citizens are free and equal and that society should be fair. He holds that justice as fairness is the most egalitarian, and also the most plausible, interpretation of liberalism's fundamental concepts.

In line with the aforementioned citation, John Rawls mentioned two principles from his A Theory of Justice as cited by Ebenstein and Ebenstein (2000) as:

\section{First Principle}

Each person is to have an equal right to the most extensive total system of equal basic liberties compatible with a similar system of liberty for all.

\section{Second Principle}

Social and economic inequalities are to be arranged so that they are both:

a) to the greatest benefit of the least advantaged, consistent with the just savings principle, and

b) attached to offices and positions open to all under conditions of fair equality of opportunity.

The first principle is also known as the Principle of Equal Basic Liberties and the second, Fair Equality of Opportunity and Difference Principle (Faiz, 2007). Being one a pre-requisite to 
the second, the two principles are in chronological order of importance. Elaborately, Rawls' principles of justice are in lexical or serial order, meaning that the first principle is more important than the second and one, more importantly, that equal basic liberties cannot be sacrificed for the greater social or economic benefits. Rawls values rights such as freedom of speech and expression, and political participation rights, above economic opportunities (Ebenstein and Ebenstein, 2000)."

\section{THE BILL OF RIGHTS}

In order to compensate with John Rawls first and second principles, Rolando Suarez (2005) mentioned the different kinds of rights which are enjoyed by a citizen of a democratic state (Art. 1. Sec. Philippines is a republican and a democratic state). These are:

1. Those rights which are God-given and need not therefore be granted by the State. They are referred to as NATURAL RIGHT. (i.e. Right to defend one's self)

2. Those rights which emanate from laws. They are referred to as STATUTORY RIGHTS. (i.e. Right to $13^{\text {th }}$ month pay)

3. Those rights which are granted by the Constitution. They are referred to as CONSTITUTIONAL RIGHTS (i.e. Those granted under Article III, Section 1, which are classified either as POLITICAL RIGHTS, CIVIL RIGHTS, SOCIAL AND ECONOMIC RIGHTS). follows:

Constitutional rights may be classified as

POLITICAL RIGHT - The right granted to citizens to participate, directly or indirectly, in the establishment or administration of government (i.e., Right to Vote.)

CIVIL RIGHT - The right enforceable at the instance of private individuals (i.e., Property Rights)

SOCIAL AND ECONOMIC RIGHT - The right intended to secure the well being and economic security of an individual (i.e., Right arising from Article XIII, 1987 Constitution), Social Justice and Human Rights, Labor, Agrarian and Natural Resources Reform, Urban Land Reform and Housing, Health, Women, Human Rights, Rights of People's Organization).

Article III (Bill of Rights) of the 1987 Philippine Constitution has guaranteed the protection of individual rights which the government is dutybound to safeguard each person under a similar system of liberty for all. Not even the government nor any other powerful entities can encroach certain rights of individuals stipulated under the bill of rights. Rolando Suarez (2005) enumerates the following summary of rights under the bill of rights:

1. Due process of law and equal protection of the laws. (Sec. 1)

2. Search and seizure (Sec. 2)

3. Privacy of communication and correspondence (Sec. 3)

4. Freedom of speech and of press (Sec. 4)

5. Freedom of religion (Sec. 5)

6. The liberty of abode and travel (Sec. 6)

7. Right to information (Sec. 7)

8. Right to association (Sec. 8)

9. Taking of private property for public use (Sec. 9)

10. Prohibition against the impairment of obligation of contracts (Sec. 10)

11. Free access to courts and quasi-judicial bodies and adequate legal assistance (Sec. 11)

12. Right to remain silent and to have a competent and independent counsel (Sec. 12)

13. Right to bail (Sec. 13)

14. Due process in criminal proceedings (Sec. 14)

15. Habeas Corpus (Sec. 15)

16. Speedy disposition of cases before all judicial, quasi-judicial or administrative bodies (Sec. 16)

17. Right against self-incrimination (Sec. 17)

18. Freedom of political belief and freedom against involuntary servitude (Sec. 18)

19. Right against excessive fines, degrading or inhumane punishment (Sec. 19)

20. Right against imprisonment for debt or nonpayment of a poll tax (Sec. 20)

21. Double jeopardy (Sec. 21)

22. Right against ex post facto law and bill of attainder (Sec. 22)

\section{BASIC EXEMPLIFICATIONS VIS-À-VIS RIGHTS OF MEN}

\section{I}

Correct: Pure intention to freely think one what thinks to be right.

Example: the intention to write manuscripts for the sake of extending good relations with others as personal etiquette, social graces, customs and traditions.

Wrong: Dirty intention to freely think one what thinks to be relatively right for the self and not for others.

Example: the intention to write manuscripts for the sake of extending personal gratification with others to satisfy one's sexual urge, to publish 
obscene pictures and liberal thoughts to filthy intentions such as maligning others with the intention to destroy the reputation and integrity of another person.

\section{II}

Correct: Each person is free to choose one's religion.

Example: At the age of $21, \mathrm{Mr}$. X shifted religion from religion $\mathrm{A}$ to $\mathrm{B}$ because he is searching for an ingrained truth of his spirituality.

Wrong: A person intends to join a religion that requires sacrificial offerings of physical bodies of human persons especially women.

Example: At the age of $21, \mathrm{Mr}$. X shifted religion from $\mathrm{A}$ to $\mathrm{B}$ because he believes that spiritual salvation of the person could be saved if one does sacrificial offerings through killing a person especially women.

\section{III}

Correct: Every person has the right to divulge issues written or spoken provided that it speaks of the truth and what is necessarily right.

Example: Mr. $\mathrm{X}$ writes an opinion in an editorial newspaper which

does not malign the integrity of others.

Wrong: When a person divulges issues that would destroy the integrity and reputation of the other.

Example: Mr. $\mathrm{X}$ writes an opinion in an editorial newspaper for revenge. He writes evil remarks against his enemy fabricating stories of immorality.

\section{IV}

Correct: Each person has the right to affiliate to any assembly or association

Example: Miss A joins leagues and unions to protect her rights against the abuses of her employer.

Wrong: A person affiliates to an organization to overthrow the government

Example: Miss A joins leagues and unions to foment revolution against the government.

Correct: Any person has the right to choose one's occupation against slavery.

Example: Mr. B works as a clerk in one of the companies in Cebu according to his free will to earn a living.

Wrong: Any person is forced to stay and work beyond normal conditions.

Example: Mr. B has been slaved as janitor. He does not get paid well and is threatened to death if he leaves his work. He is required to work beyond normal work schedules.

\section{CALL TOWARDS JUSTICE}

For those people who experience injustice in whatever form, it is very important for them to know and apply their basic rights mentioned above. However, achieving social justice is not a one-way process. It requires the cooperation between the people and the government. The concept of social justice is ideal because there is no such thing as "perfect state". It only becomes real when it is practiced not only by the government but the citizens in a state. A person cannot separate himself outside the bounds of government control. The government is an agency that regulates the conduct of all men. However, there are limitations along their administration. This is where people have to consider some limitations of the government. This can be done when each person is vigilant of his rights and rightful of his actions under the merit of equality through fairness. Each citizen's rights should not be compromised under Rawls' first principle of justice. However, under his second principle, human nature has bestowed social and economic inequality. This is where each person should empower himself (not merely relying on the government) according to one's capacity to do rightful actions for others. With the government's failure (limitation) to address the socio-economic plight of the masses, it is now, therefore, the responsibility of those less-privileged to be self-reliant on their own. Complete salvation could not be achieved by depending on the government alone but through the individual who saves himself under the merit of distributive, legal and commutative justice. This is what we call DO-

\section{IT-FOR-YOURSELF-FOR-OTHERS.}

Government's basic programs and services for the poor are inherent within its operations. One can avail it but it is better if one does not rely to it fully.

A positive perception about the government is difficult to achieve when they (government) fail under the present political and socio-economic conditions. Though one cannot deny that the socioeconomic status of the person affects his exercise of individual liberty, it is already time to save one self for the sake of others. This requires positive outlook towards the society in which the government is a member. This is hard to establish but it takes generation to generation to transmit this political culture from one period to another time. According to Moten and Islam, "Political values, beliefs and emotions of a political culture are passed on to succeeding generations through the process of political socialization... The process starts at an early age and continues throughout life. The institutions of family, school, religion, employment, club, mass media, political party and legislature are the agencies of political socialization. All of them help to cement the cultural heritage (2006)." Thus, each person is 


\begin{tabular}{|c|c|c|c|c|c|c|}
\hline Impact Factor: & $\begin{array}{l}\text { ISRA (India) } \\
\text { ISI (Dubai, UAE } \\
\text { GIF (Australia) } \\
\text { JIF }\end{array}$ & $\begin{array}{l}=1.344 \\
=0.829 \\
=0.564 \\
=1.500\end{array}$ & $\begin{array}{l}\text { SIS (USA) } \\
\text { PИНЦ (Russia } \\
\text { ESJI (KZ) } \\
\text { SJIF (Morocco }\end{array}$ & $\begin{array}{r}=\mathbf{0 . 9 1 2} \\
=\mathbf{0 . 2 3 4} \\
=\mathbf{1 . 0 4 2} \\
=\mathbf{2 . 0 3 1}\end{array}$ & $\begin{array}{l}\text { ICV (Poland) } \\
\text { PIF (India) } \\
\text { IBI (India) }\end{array}$ & $\begin{array}{l}=6.630 \\
=1.940 \\
=4.260\end{array}$ \\
\hline
\end{tabular}

responsible in disseminating concepts about justice necessary to establish a strong republican state.

\section{CONCLUSIONS}

The government's effort in solving Philippine political socio-economic problems is clearly evident in its operation. Despite mechanisms, the government has certain limitations in addressing the needs of all its citizens, thereby, creating a very negative outlook among its constituents. Although there were positive responses that merit the recognition of good laws and policies in the Philippines, governance and implementation of the aforementioned turned out to be the problem. For future researchers who are willing to undertake scholarly researches, the following are suggested:

A. Socialism and Rawls' Theory of Justice: A Political Socio-Economic Analyses.

B. Cebuano Political and Socio-Economic Awareness and Attitude: Its Impact to Philippine Development.

C. Cebuano Political Value Orientation towards the Philippine Development: A SocioAnthropological Study.

D. Philippine Human Rights Issues and Concerns: A Discourse Analysis.

\section{References:}

1. Dannug and Campanilla (2004) Politics, Governance and Government with Philippine Constitution. Quezon City: C \& E Publishing, Inc.

2. Ebenstein, William and Alan (2000) Great Political Thinkers. Singapore: Thomson Learning Asia

3. Merriam-Webster's Pocket Dictionary. (1995) Philippines: Merriam-Webster, Incorporated

4. Moten AR, Islam SS (2007) Introduction to Political Science. Singapore: Thomson Learning

5. Suarez Rolando (2005) The 1987 Constitution of the Republic of the Philippines Made Easy. Quezon City: Rex Printing Company, Inc.

6. (2008) Available: http://www.iep.utm.edu/r/rawls.htm

(Accessed: July 2, 2008)

7. (2008) Available: http://faizlawjournal.blogspot.com/2007/01/ john-rawlss-theory-of-justice.html (Accessed: June 2, 2008)
8. (2008) Available: http://www.germanlawjournal.com/article.p hp?id=208 (Accessed: July 2, 2008)

9. (2008) Available: http://ptx.sagepub.com/cgi/content/abstract/ 35/6/756 (Accessed: July 4, 2008)

10. (2008) Available: http://opinion.inquirer.net/inquireropinion/c olumns/view_article.php?article_id=106988 (Accessed: July 6, 2008)

11. (2008)

Available: http://opinion.inquirer.net/inquireropinion/c olumns/view/20071229-

109332/Statistics for_justice (Accessed: July 15, 2008)

12. (2008) Available: http://plato.stanford.edu/entries/rawls/ (Accessed: July 17, 2008)

13. (2008) Available: http://www.scu.edu/ethics/practicing/decisio n/justice.html (Accessed: September 5, 2008).

14. http://www.iep.utm.edu/a/aq-moral.htm (Accessed: September 7, 2008). 